Nippon Suisan Gakkaishi $\quad$ 82(5), 816 (2016)

\title{
シンポジウム記録 地下水・湧水を介した陸一海のつながり
}

\section{III-3. 水利用とエネルギー利用のトレードオフ 〜温泉水利用, 河川生態系などの側面を中心に〜}

\author{
山田 誠 \\ 総合地球環境学研究所
}

III-3. Trade-off of the water use and the energy use -Topic about relations with hot spring water use and the river ecosystem-

MAKOTO YAMADA

Research Institute for Humanity and Nature, Kitau, Kyoto 603-8047, Japan

温泉水は，古来より浴用のみならず，飲用・熱利用な ぞ様々な形で人々に利用されている。温泉水は利用後, 排水として下水処理されるはずであるが，下水が完備さ れていない地域や高温のため下水に流せない場合などは そのまま河川に排出される場合がある。世界でも有数の 源泉数を誇る大分県別府市の場合, 温泉排水が高温のた め下水へ流すことができず，河川へ排水されるため，温 泉由来の物質が河川へ々流入し，そのまま沿岸域へ流出 している。 ${ }^{1)}$ また，そこでは，熱帯性の魚類が多数生息 していることが知られており,2) それらは容易に目視で 確認できるほどである。

一方, 東日本大震災後, 再生可能エネルギーの一つと して, 温泉水の熱を利用した温泉熱発電が注目されてい る。温泉熱発電は, 浴用には温度の高すぎる温泉水を浴 用に適した温度まで冷却する過程で得られるエネルギー を電力へと変える，これまで無䭾にしてきたエネルギー を利用できる発電方法であると言われている。別府市で も, 温泉熱発電の導入が進んで扔り, 発電用として利用 できるという用途の増加によって, 温泉水の利用価值が これまで以上に高くなってきている。

このように, 一方では, 利用後又は未利用の温泉水が 他の水系へと流入し，それが水域の生態系に対して影響 を与えて抢り，また一方では，温泉水に対する需要が高 まりつつあるという現状は, 別府の久ならず, 様々な地 域で温泉熱利用と周辺水域の生態系との間でトレードオ フが生じる可能性があると言えよう.

Yamada et al. ${ }^{3)}$ は, 別府市の温泉排水が流入する河 川で魚類と温泉排水の関係について研究を行い, 温泉排 水が温度と食料の両面で, 熱帯性の魚（ナイルティラピ ア）が生息するのに適した環境を作り出していることを 明らかにした。これは, 温泉利用が生態系の变化を引き
起こしている典型的な事例と考えらえるが，この研究が 行われた河川では漁業などの経済活動は行われておら ず，生態系が変化することにより影響を被るステークホ ルダーが存在しないため, 明確なコンフリクトは生じて いない。しかし，温泉の利用が増大すると生態系に対す る負荷が大きくなるという点では, 温泉利用と河川生態 系の間でトレードオフの関係が成り立っていると言える。

このようなトレードオフの関係を解消するには, 少な くとも, ナイルティラピアにとって不適な河川温度環境 を維持する必要があり, そのためには温泉排水の量と温 度をコントロールする必要がある。現状把握のために現 在の流入排水の平均温度を見積もると, 平均温度が 35 ${ }^{\circ} \mathrm{C}$ で 0.2 ton $/ \mathrm{s}$ 程度の排水が流入していることがわかっ た。少なくとも，排水の平均温度をそれよりも低くする か, 流入する量を減らさない限り, ナイルティラピアに とって不適な河川温度環境を形成することはできない。

温泉排水は, $96^{\circ} \mathrm{C}$ 程度のものや $60^{\circ} \mathrm{C}$ 程度のものな ぞ, 様々な温度の排水で構成されている。高温の排水 は, 前述の温泉熱発電に利用できる可能性があり, 30 ${ }^{\circ} \mathrm{C} \sim 40^{\circ} \mathrm{C}$ 程度の低温のものでも，その温度帯でドジョ ウの養殖のような水産資源の育成への利用例があること などから，エネルギーとしての利用が可能と考えらえ る。温泉排水の量を減らすことは経済活動を制限するこ とにつながることから，容易ではないと思われるが，様 々な段階で温泉熱を利用する, いわゆるカスケード利用 をすることで熱エネルギーを消費し, 流入する排水の温 度を下げることは，実利につながるという面でも，非常 に有用な手段であると考えられる。カスケード利用によ る温泉排水の温度コントロールは, 温泉利用と生態系と のトレードオフを解消, もしくは低減することができる 可能性を秘めていると考えている。

\section{文献}

1）酒井拓哉, 川野田実夫, 大沢信二, 馬渡秀夫, 山田 誠, 三島壮智. 別府地域の河川水質への温泉排水の影響評価. 大分県温泉調査研究会報告 $2011 ; 62: 47-58$.

2) 平松恒彦, 松尾敏生, 佐藤眞一. 別府地域における淡水の 水生動物. 別府の自然 : 別府市自然環境学術調査報告書, 別府. 1994; 323-344.

3) Yamada M, Shoji J, Ohsawa S, Mishima T, Hata M, Honda $\mathrm{H}$, Fujii M, Taniguchi M. Hot spring drainage impact on fish communities around temperate estuaries in southwestern Japan. J Hydrol.: Regional Studies 2016; doi:10.1016/j.ejrh.2015.12.060 